\title{
PELAKSANAAN PEMBUATAN AKTA AUTENTIK OLEH NOTARIS DI KABUPATEN LIMA PULUH KOTA
}

\author{
UMUL KHAIR \\ Sekolah Tinggi Ilmu Hukum Putri Maharaja Payakumbuh \\ khair_ummul78@yahoo.com
}

\begin{abstract}
Notaries are public officials authorized to make authentic deeds and other authorities. Meanwhile, agreements made in writing before a notary or government official have perfect evidentiary power. Implementation of Authentic Deed Making by a Notary in Fifty Cities District the parties/appearers come to consult with the notary's office of consultation and convey what they want, the notary explains everything to the parties/appearers if everything has been completed by the parties/appearers, the deed will be signed by the parties (minuta/deed) and a copy will be issued by a notary, so based on the research the author did on the implementation of making an authentic deed by a notary in the District of Fifty Cities, it was in accordance with the Standard Operating Procedure (SOP), but was not maximized due to several obstacles. namely: the parties/appearers who came to the notary's office did not understand the notary deed and thought that the cost of making a notary deed was high and because the management system was on line, both CV, PT and Foundation, when the network had problems, the timing did not match the initial predictions of the parties. The solutions are as follows: increasing the understanding of the parties/appearers about the authentic deed, providing explanations to the parties/appearers about the procedure for making a notarial deed, explaining to the parties/appearers who come to the notary's office and changing the mindset and assumptions of the parties/appearers regarding the cost of making a notarial deed is high as well as providing explanations and understanding to the parties/appearers because the management system is online, when the network is in trouble, the time is not in accordance with the initial predictions of the parties/appearances. The suggestions are as follows: that the notary must be more careful in examining and making the deed, it is hoped that it will be a comprehensive renewal and reorganization in a law that regulates the position of a notary so that legal knowledge is created that applies to all residents throughout the territory of the State of Indonesia.
\end{abstract}

Keywords: Implementation, Making, Authentic Deed, Notary.

Abstrak: Notaris adalah pejabat umum yang berwenang membuat akta otentik dan kewenangan lainnya. Sedangkan perjanjian yang dibuat secara tertulis dihadapan notaris atau pejabat pemerintahan memiliki kekuatan pembuktian yang sempurna. Pelaksanaan Pembuatan akta Autentik Oleh Notaris di Kabupaten Lima Puluh Kota para pihak/penghadap datang melakukan konsultasi kekantor notaris konsultasi dan menyampaikan apa yang menjadi keinginannya, notaris menjelaskan semuanya kepada para pihak/penghadap kalau sudah dilengkapi semuanya oleh para pihak/ penghadap, maka akan ditandatangani akta oleh para pihak ( minuta/akta) dan akan dikeluarkan salinannya oleh notaris, jadi berdasarkan penelitian yang penulis lakukan terhadap Pelaksanaan Pembuatan akta Autentik Oleh Notaris di Kabupaten Lima Puluh Kota telah sesuai dengan Standar Operasional Prosedurnya (SOP), tetapi belum maksimal dengan adanya beberapa kendala yaitu: para pihak/penghadap yang datang kekantor notaris tidak memahami tentang akta notaris dan beranggapan tentang biaya Pembuatan akta notaris tinggi dan karena sistim pengurusannya on line baik CV,PT maupun Yayasan, ketika jaringan bermasalah maka waktunya tidak sesuai dengan prediksi awal para pihak. Jalan keluar adalah sebagai berikut: meningkatkan pemahaman para pihak/penghadap tentang akta autentik, memberikan penjelasan kepada para pihak/penghadap tentang prosedur pembuatan akta notaris, menjelaskan kepada para pihak/penghadap yang datang kekantor notaris dan merubah pola pikir serta anggapan para pihak/penghadap tentang biaya pembuatan akta notaris tinggi serta memberikan penjelasan dan pemahaman kepada para pihak/penghadap karena sistim pengurusannya on line, ketika jaringan bermasalah maka waktunya tidak sesuai 
dengan prediksi awal para pihak/penghadap tersebut. saran sebagai berikut : agar notaris harus lebih teliti lagi dalam memeriksa dan membuat akta, diharapkan menjadi pembaharuan dan pengaturan kembali secara menyeluruh dalam suatu Undang-undang yang mengatur Jabatan Notaris sehingga terciptalah pengetahuan hukum yang berlaku untuk semua penduduk di seluruh wilayah Negara Indonesia.

Kata Kunci: Pelaksanaan, Pembuatan, Akta Autentik, Notaris.

\section{A. Pendahuluan}

Hukum perdata secara umum adalah himpunan peraturan-peraturan (kaidah-kaidah) yang berlaku dalam suatu masyarakat tertentu dan bertujuan mengatur kepentingan perorangan dari anggota masyarakat, hukum perdata berlaku dan ada dalam kehidupan masyarakat seharihari dan menjadi bagian yang tidak dapat dipisahkan dari setiap gerak langkah masyarakat karena mengatur hal-hal yang terjadi dalam kehidupan bermasyarakat, berbangsa dan bernegara. Notaris berwenang membuat akta otentik mengenai semua perbuatan, perjanjian, dan ketetapan yang diharuskan oleh peraturan perundang-undangan dan/atau yang dikehendaki oleh yang berkepentingan untuk dinyatakan dalam akta otentik, menjamin kepastian pembuatan akta, menyimpan akta, memberikan grosse, salinan dan kutipan akta, semuanya itu sepanjang pembuatan akta-akta itu tidak juga ditugaskan atau dikecualikan kepada pejabat lain atau orang lain yang ditetapkan oleh undang-undang sebagaimana diatur dalam Pasal 15 ayat (1) Undang-Undang Nomor 2 Tahun 2014 Tentang Perubahan Atas Undang-Undang Nomor 30 Tahun 2004 Tentang Jabatan Notaris (selanjutnya disebut UU Perubahan Atas UUJN).

Peran notaris sebagai pejabat umum yang diangkat oleh mentri atau pejabat yang ditunjuk semakin besar terkait dengan semakin maraknya orang-orang membuat perjanjian atau perikatan. Hal ini terjadi karena notaris berwenang membuat akta otentik yang mampu memberi perlindungan kepada pihak-pihak yang melakukan perjanjian. Undang-undang menyatakan bahwa notaris sebagai pejabat umum yang diberi mandat untuk membuat akta otentik, sebab akta yang dibuat notaris mempunyai kekuatan pembuktian yang sempurna, dikarenakan sifat otentik yang dimiliki atas akta-akta yang dibuatnya.

Notaris adalah pejabat umum yang berwenang membuat akta otentik dan kewenangan lainnya. Notaris merupakan suatu profesi yang dilatarbelakangi dengan keahlian khusus yang ditempuh dalam suatu pendidikan dan pelatihan khusus, hal ini menuntut notaris untuk memiliki pengetahuan yang luas serta tanggung jawab untuk melayani kepentingan umum. Notaris dalam menjalankan tugasnya harus memegang teguh dan menjunjung tinggi martabat profesinya. Dalam melayani kepentingan umum, notaris dihadapakan dengan berbagai macam karakter manusia serta keinginan yang berbeda-beda dari para pihak yang datang kepada notaris untuk dibuatkan suatu akta otentik atau sekedar legalisasi sebagai bukti tertulis atas suatu perjanjian yang dibuatnya.

Notaris adalah Pejabat umum yang diangkat oleh Pemerintah untuk membantu masyarakat umum dalam hal membuat perjanjian-perjanjian yang ada atau timbul dalam masyarakat. Perlunya perjanjian-perjanjian tertulis ini dibuat dihadapan seorang notaris adalah untuk menjamin kepastian hukum bagi para pihak yang melakukan perjanjian. Perjanjian digunakan dalam berbagai hubungan bisnis, kegiatan di bidang perbankan, pertanahan, kegiatansosial, dan lain-lain, kebutuhan akan pembuktian tertulis berupa akta otentik makin meningkat sejalan dengan berkembangnya tuntutan akan kepastianhukum dalam berbagai hubungan ekonomi dan sosial, baik pada tingkatnasional, regional, maupun global.

Notaris produk akhirnya yaitu akta otentik. Akta otentik sebagai alat bukti terkuat dan terpenuh mempunyai peranan penting dalam setiap hubungan hukum dalam kehidupan masyarakat. Begitu pentingnya fungsi dari akta Notaris tersebut, oleh karena itu untuk menghindari tidak sahnya dari suatu akta, maka lembaga Notaris diatur didalam Peraturan Jabatan Notaris untuk selanjutnya ditulis (PJN), yang telah diganti oleh Undang-Undang Nomor 30 Tahun 2004 Tentang Jabatan Notaris dan selanjutnya disebut Undang-Undang Jabatan Notaris yang disingkat UUJN. Pada tanggal 6 Oktober 2004 diundangkan Undang- 
Undang Nomor 30 Tahun 2004 Tentang Jabatan Notaris. Diundangkannya UUJN ini tentu saja disambut baik oleh kalangan Ilmu Hukum, Hukum Notariat, dan masyarakat pada umumnya terlebih lagi mereka yang biasa menggunakan layanan dari notaris. Notariat, dalam posisi Pejabat Notaris dan Hukum Notaris secara umum kini lebih efisien menuju kodifikasi yang positif. Sejak berlakunya UUJN peraturan perihal jabatan dan Hukum Notaris sudah terkodifikasi didalam satu Undang-Undang saja. Kondisi seperti ini membuat hukum menjadi lebih efisien dengan harapan dapat mendukung aktifitas perikatan menjadi lebih teratur dan ada kepastian hukum, dalam rangka menuju kepada tujuan hukum itu sendiri yang salah satunya adalah keadilan. Kewenangan notaries sebagaimana dimaksud didalam Pasal 15 UUJN dengan profesinya sebagai pembuat akta otentik disertai dengan perkembangan kebutuhan masyarakat yang begitu pesat dan dinamis telah meningkatkan intensitas dan kompleksitas hubungan hukum yang tentunya memerlukan kepastian, ketertiban, dan perlindungan hukum yang berintikan kebenaran dan keadilan (Subekti, 1981).

Menjalankan kewenangannya notaris dalam membuat suatu akta notaris harus sesuai dengan ketentuan yang diatur di dalam UUJN, apabila tidak memenuhi salah satu atau beberapa unsur tersebut maka suatu akta notaris tersebut mengakibatkan kebatalan maupun pembatalan akta notaris. Hal ini menunjukkan bagaimana pertanggungjawaban notaris dalam melaksanakan kewenangan maupun kewajibannya. Dalam kenyataannya notaris nakal jelas ada. Tetapi notaris yang menjadi sasaran pemerasan juga ada. Di dalam prakteknya ada notaris yang melakukan penyimpangan atau kesalahan di dalam membuat akta notaris, baik itu disebabkan karena ketidakjujuran notaris itu sendiri atau para pihak yang menghadap.

Notaris menurut Undang-Undang Nomor 2 Tahun 2014 Republik Indonesia Tentang Jabatan Notaris Pasal 1 ayat (1) Notaris adalah: "Pejabat umum yang berwenang untuk membuat akta otentik dan kewenangan lainnya sebagaimana dimaksud dalam undang-undang ini atau berdasarkan undang-undang lainnya. Akta otentik merupakan salah satu alat bukti tulisan di dalam bentuk yang ditentukan oleh undang-undang, dibuat oleh atau dihadapan pejabat/pegawai umum yang berkuasa untuk itu ditempat dimana akta dibuatnya sebagai bunyi ketentuan pasal 1867 dan pasal 1868 Kitab Undang-undang Hukum perdata (KUHPer) (Herlien Budiono, 2012). Dalam kehidupan bermasyarakat tidak bisa terlepas dari hubungan satu dengan lainnya. Yang paling sering dilakukan oleh seseorang maupun badan hukum untuk menjaga/mengikat hubungan tersebut adalah melalui sebuah Perjanjian/kontrak. Membuat kesepakatan melalui sebuah Perjanjian tersebut bisa saja dikarenakan dalam rangka memenuhi kebutuhan hidup ataupun dalam rangka memperoleh keuntungan. Misalnya perjanjian transaksi jual beli, sewa menyewa, pinjam-meminjam, menggunakan jasa seseorang, dan sebagainya.

Kebanyakan masyarakat di Indonesia, Khususnya masyarakat di Kabupaten Lima Puluh Kota berdasarkan pengamatan awal dari peneliti masih kurang paham betul akan pentingnya melakukan perjanjian secara tertulis, masyarakat beranggapan biaya pembuatan akta yang tinggi serta mereka masih banyak yang melakukan dengan perjanjian lisan, walaupun perjanjian lisan tidak dilarang oleh KUHP Perdata, namun perjanjian lisan tidak memiliki kekuatan hukum yang kuat dibandingkan perjanjian dalam bentuk tertulis. Sedangkan perjanjian yang dibuat secara tertulis dihadapan notaris atau pejabat pemerintahan memiliki kekuatan pembuktian yang sempurna. Banyak pula masyarakat yang melakukan perjanjian tertulis namun perjanjian tersebut tidak memenuhi syarat sahnya perjanjian yang terkandung dalam pasal 1320 KUH Perdata. Oleh karena itu, tulisan ini bertujuan untuk memberikan pengetahuan tentang bagaimana suatu perjanjian dianggap sah menurut Kitab Undang-Undang Hukum Perdata (KUHP). Agar dapat dijadikan pembelajaran bagi masyarakat menegenai suatu perjanjian atau kontrak.

\section{B. Metodologi Penelitian}

Untuk memudahkan membahas setiap permasalahan dalam penulisan ini, maka disamping itu pengumpulan bahan dan data-data yang erat kaitannya dengan pokok bahasan atau permasalahan dalam penulisan ini, perlu dilakukan penelitian. Adapun metode yang 
dilakukan dalam penelitian ini adalah yuridis empiris yakni penelitian yang menguji efektifitas hukum dalam pelaksanaannya di lapangan.

\section{Hasil dan Pembahasan}

1. Pelaksanaan Pembuatan akta Autentik oleh Notaris di Kabupaten Lima Puluh Kota

Berdasarkan wawancara dengan Ibu Elza Fitri S.H.,MKn sebagai salah seorang Notaris

di Kabupaten Lima Puluh Kota mengenai Pelaksanaan Pembuatan akta Autentik oleh Notaris di Kabupaten Lima Puluh Kota adalah sebagai berikut: 1) Para pihak/penghadap datang melakukan konsultasi kekantor notaris konsultasi dan menyampaikan apa yang menjadi keinginannya, misalnya ingin mendirikan CV (Comanditeir Vennonscap); 2) Notaris menjelaskan semuanya kepada para pihak/penghadap apa itu CV (Comanditeir Vennonscap), syarat mendirian CV (Comanditeir Vennonscap), dimana kedudukannya, maksud dan tujuannya, struktur kepengurusannya apakah akan menjadi anggota pasif, atau anggota pasif dengan rinci. 3) Para pihak/penghadap biasanya menanyakan biaya administrasi dan notaris akan menjelaskan nya, bahkan ada para pihak /penghadap yang menawar biaya administrasinya tersebut, karena dianggap oleh penghadap cukup mahal; 4) Memenuhi segala teknik administratif pembuatan akta Notaris, seperti pembacaan, penandatatanganan, memberikan salinan, dan pemberkasan, dan dalam hal ini kebanyakan para pihak/penghadap yang datang, banyak yang kurang memahaminya; 5) Kalau sudah dilengkapi semuanya oleh para pihak/ penghadap, maka akan ditandatangani akta oleh para pihak ( minuta/akta) dan akan dikeluarkan salinannya oleh notaries dan ditandatangani diatas materai; dan 6) Semua pengurusannya itu kadangkala membutuhkan waktu yang tidak sama setiap para pihak/penghadap, contohnya apabila on-line karena jaringan bermasalah maka waktunya tidak sesuai dengan prediksi awal para pihak/penghadap pengurusan akta CV (Comanditeir Vennonscap) tersebut dari awal sampai selesainya akta tersebut.

Kemudian berdasarkan wawancara yang penulis lakukan dengan Notaris Khairul Nas S.H.,MKn salah seorang Notaris di Kabupaten Lima Puluh Kota mengenai Pelaksanaan Pembuatan akta Autentik oleh Notaris di Kabupaten Lima Puluh Kota adalah sebagai berikut: 1) Para pihak/penghadap datang kekantor notaris memperkenal kan diri dan berkonsultasi serta menyampaikan apa yang ingin menjadi tujuannnya Yaitu ternyata ingin mendirikan sebuah PT (Perseroan Terbatas); 2) Notaris akan menjelaskan semuanya kepada para pihak/penghadap apa itu PT, syarat mendirian PT, dimana kedudukannya, maksud dan tujuannya, dan struktur kepengurusannya dengan jelas dan rinci; 3) Draft akta dirancang oleh notaris dan dicek dahulu oleh para pihak /penghadap yang meminta akta dibuat. Kemudian dilakukan jadwal tanda tangan yang dihadiri pengurus perusahaan berhadapan dengan notaris, Hal ini kadang sulit dilakukan karena sulit menghadirkan para pihak tersebut yang mana domosilinya berjauhan karena ada yang diluar kota apalagi dengan covid-19 sekarang ini agak kesulitan untuk menghadiri semuanya itu. Yang dimaksud dengan para pihak/penghadap untuk PT adalaah pemegang saham perusahaan; 4) Kalau sudah dilengkapi semuanya oleh para pihak/ penghadap, maka akan ditandatangani akta oleh para pihak (minuta/akta) dan akan dikeluarkan salinannya oleh notaries dan ditandatangani diatas matrai; 5) Kalau Akta Pendirian perusahaan sudah diterbitkan, maka Notaris harus mengajukan pengesahan PT tersebut sebagai Badan Hukum. Kemenkumham akan menerbitkan SK (Surat Keputusan) pengesahan Badan Hukum. Dengan begitu, perusahaan /PT tersebut sudah sah dan diakui oleh negara.

Sedangkan berdasarkan hasil wawancara penulis dengan Notaris Bapak Zainal Rajab S.H.,MKn mengenai pelaksanaan pembuatan akta autentik oleh notaries adalah sebagai berikut: 1) Para pihak/penghadap datang kekantor dengan memperkenalkan diri lebih dulu dan memperlihakan odentitasnya, serta menyampaikan maksud dan tujuannnya datng tersebut yaitu ingin mendirikan yayaasan. 2) Sebagai Notaris maka akan menjelaskan dulu apa itu yayasan dengan rinci kepada para pihak/penghadap. 3) Selanjutnya Notarislah yang akan mengawal proses pendirian Yayasan, mulai dari pemesanan nama, pengajuan permohonan 
pengesahan badan hukum Yayasan kepada Menteri, hingga penerimaan berkas-berkas proses jadinya Yayasan. 4) Bila syarat-syarat tersebut sudah lengkap, maka para pendiri bersamasama menghadap Notaris untuk menandatangani akta pendirian. Yayasan ini sudah dianggap berdiri sejak ditandatanganinya akta pendirian oleh para pendiri di hadapan Notaris. Namun Yayasan ini belum sah menjadi Badan Hukum. Untuk itu Notarislah yang akan segera memproses pengesahan badan hukum Yayasan ke Kementrian Hukum dan HAM. 5) Setelah Akta Pendirian Yayasan ini disahkan sebagai badan hukum oleh Menteri Hukum dan HAM. maka Yayasan dianggap sebagai pihak yang dapat melakukan perbuatan hukum yag secara hukum juga bertanggung jawab atas apa yang dikerjakannya. Jadi pertanggungjawaban itu melekat setelah Akta Pendirian Yayasan disahkan oleh Menteri.

Menurut Sujono Sukanto, kesadaran hukum adalah terbanyak dari kesadaran-kesadaran hukum individu mengenai peristiwa tertentu dan merupakan kekuatan hukum mengikat dari anggota masyarakat untuk mau memahami, melaksanakan dan menjalankan hukum dalam kehidupan sehari-hari, kesadaran hukum masyarakat sangat dibutuhkan untuk sehingga mereka tidak mengetahui apa guna mereka mebuat Hubungan hukumnya dengan akta notaris, hal inilah yang harus kita tingkatkan, karena tanpa kesadaran maka pemahaman masyarakat, tentang akta autentik tidak akan meningkat, diperlukan upaya-upaya oleh pemerintah dan instansi terkait untuk membeberkan penyuluhan hukum kepada masyarakat yang tidak memahami hukum terutama tentang pembuatan akta notaris, walaupun pada saat ini pemerintah telah banyak mengangkat notaris namun hal tersebut belum memenuhi keinginan masyarakat karena pendidikan hukum sangat dibutuhkan oleh masyarakat maka pendidikan dan pengetahuan tentang hukum mempunyai peranan yang sangat penting dalam masyarakat, pendidikan hukum sangat berfungsi untuk mempertahankan stabilitas masyarakat dan mampu mengubah masyarakat dari ngetahuan masyarakat tentang disini diharapkan para notaris dan para mahasiswa lulusan Fakultas Hukum untuk memberikan pendidikan hukum menjadi mengetahui dan memahami sehingga mampu menjalankannya dalam kehidupan bermasyarakat hukum dan tentang akta notaris.

Kekuatan Pembuktian Formil (Formil Bewijskracth) Kekuatan pembuktian formal ini didasarkan atas benar tidaknya ada pernyataan oleh yang bertanda tangan di bawah akta itu. Dalam akta otentik, pejabat pembuat akta menyatakan dalam tulisan itu bahwa ada yang dinyatakan dalam akta itu sebagaimana telah dicantumkan di dalamnya. Pada ambtelijke akten, pejabat pembuat akta lah yang menerangkan apa yang dikonstatia oleh pejabat itu dan menuliskannya dalam akta, dan oleh sebab itu apa yang diterangkan oleh pejabat tadi telah pasti bagi siapapun, sepanjang mengenai tanggal pembuatan, tempat pembuatan akta dan isi/ keterangan dalam akta itu. Dalam partij akte sebagai akta otentik, bagi siapapun telah pasti bahwa pihak-pihak dan pejabat yang bersangkutan menyatakan seperti apa yang tertulis di atas tanda tangan mereka. Dalam hal ini, sudah pasti adalah: tanggal pembuatan akta, dan keaslian tanda tangan pejabat dan para pihak serta saksi-saksi yang turut menandatangani akta tersebut, serta kepastian bahwa para pihak ada menerangkan seperti apa yang diuraikan atau dicantumkan dalam akta itu, sedang kebenaran dari apa yang diterangkan oleh para pihak itu pada hakikatnya hanya pasti antara mereka sendiri. Akta di bawah tangan baru mempunyai kekuatan pembuktian formal, jika tanda tangan di bawah akta itu diakui/ tidak disangkal kebenarannya. Dengan diakuinya keaslian tanda tangan pada akta di bawah tangan, maka kekuatan pembuktian formal dari akta di bawah tangan itu sama dengan kekuatan pembuktian formal dari akta otentik.

Kekuatan Pembuktian Materil (Materiele Bewijskracth) Kekuatan pembuktian materil ini menyangkut pembuktian tentang materi suatu akta, memberi kepastian tentang peristiwa bahwa pejabat dan para pihak melakukan atau melaksanakan seperti apa yang diterangkan dalam akta itu. Akta pejabat sebagai akta otentik, tidak lain hanya membuktikan apa yang disaksikan, yakni yang dilihat, didengar dan juga dilakukan sendiri oleh pejabat itu dalam menjalankan jabatannya. Akta para pihak menurut Undang-Undang merupakan bukti sempurna bagi mereka dan ahli warisnya dan sekalian orang yang mendapat hak darinya. Akta di bawah tangan, jika tanda tangan di dalam akta itu tidak dimungkiri keasliannya, serupa 
dengan partij akten sebagai akta otentik, mempunyai kekuatan pembuktian materil bagi yang menandatanganinya, ahli warisnya serta para penerima hak dari mereka, sebagaimana ditentukan dalam Pasal 1875 Kitab UndangUndang Hukum Perdata (Pasal 288 Rbg).

Akta Otentik Sebagai Alat Bukti Pada dasarnya akta otentik adalah suatu akta yang dibuat sesuai dengan ketentuan perundang-undangan oleh atau di hadapan seorang pegawai umum yang berwenang membuat surat itu dengan maksud untuk digunakan sebagai alat bukti. Maksud dari pegawai umum di sini adalah Hakim, Notaris, Panitera, Jurusita, Pegawai Catatan Sipil, Camat. Apabila dilihat dari pengertian dari akta otentik itu sendiri, dapat disimpulkan bahwa otentik atau tidaknya suatu akta tidak cukup apabila akta itu dibuat oleh atau dihadapkan pegawai umum, tetapi juga cara pembuatannya harus menurut ketentuan yang terdapat dalam Peraturan Perundang-undangan. Suatu akta yang dibuat oleh pejabat yang tidak berwenang dan tanpa adanya kemampuan untuk membuatnya atau tidak memenuhi syarat-syarat tertentu, tidak dianggap sebagai akta otentik tetapi mempunyai kekuatan sebagai akta di bawah tangan.

Dari penjelasan di atas, dapat disimpulkan bahwa suatu akta otentik pada dasarnya mengandung 3 (tiga) macam kekuatan pembuktian, yaitu: a) Kekutan pembuktian formil, yang berarti membuktikan antara para pihak bahwa mereka telah menerangkan apa yang ditulis dalam akta tersebut; b) Kekuatan pembuktian materiil, yang berarti membuktikan antara para pihak, bahwa benar peristiwa yang tersebut dalam akta tersebut telah terjadi; dan c) Kekuatan pembuktian keluar, yang berarti disamping sebagai pembuktian antara mereka juga terdapat pihak ketiga di mana pada tanggal, bulan, dan tahun yang tersebut dalam tersebut telah menghadap kepada pegawai menerangkan apa yang terdapat dalam akta tersebut.

Berdasarkan hasil penelitian penulis tentang akta autentik dalam melakukan hubungan hukum ditengah-tengah masyarakat pada saat ini menurut penelitian penulis masih kurang, diantaranya masyarakat yang membuat akta dikantor notaris, adapun alasan mereka datang ke kantor notaris untuk membuat akta notaris adalah: 1) Bahwa untuk melakukan jual beli tanah diharuskan untuk membuat akta jual beli dikantor notaris; 2) Untuk membuat perjanjian ini maka para pihak menghendaki untuk dibuat dikantor notaris, karena dengan akta notaris lebih terjamin kepastian hukumnya; 3) Karena dengan dibuatnya akta di kantor notaris maka diantara para pihak tidak ada lagi keraguan dan pertengkaran dikemudian hari karena dengan akta notaris semuanya menjadi jelas sehingga tidak ada salah satu pihak yang dirugikan; 4) Masyarakat yang membuat akta di kantor notaris mengetahui bahwa sebaiknya membuat akta hubungan hukum berupa perjanjian adalah dikantor notaris diantaranya responden memberi jawaban: a) Dari teman-teman yang telah pernah membuat akta notaris, b) Dari keluarga mereka yang mempunyai pendidikan dibidang hukum, dan c) Responden sendiri tahu bahwa untuk membuat akta di kantor notaries.

Jadi pada dasarnya akta otentik adalah suatu akta yang dibuat sesuai dengan ketentuan perundang-undangan oleh atau di hadapan seorang pegawai umum yang berwenang membuat surat itu dengan maksud untuk digunakan sebagai alat bukti. Maksud dari pegawai umum di sini adalah Hakim, Notaris, Panitera, Jurusita, Pegawai Catatan Sipil, Camat. Apabila dilihat dari pengertian dari akta otentik itu sendiri, dapat disimpulkan bahwa otentik atau tidaknya suatu akta tidak cukup apabila akta itu dibuat oleh atau dihadapkan pegawai umum, tetapi juga cara pembuatannya harus menurut ketentuan yang terdapat dalam Peraturan Perundangundangan. Suatu akta yang dibuat oleh pejabat yang tidak berwenang dan tanpa adanya kemampuan untuk membuatnya atau tidak memenuhi syarat-syarat tertentu, tidak dianggap sebagai akta otentik tetapi mempunyai kekuatan sebagai akta di bawah tangan.

Dari penjelasan di atas, dapat disimpulkan bahwa suatu akta otentik pada dasarnya mengandung 3 (tiga) macam kekuatan pembuktian, yaitu: a) Kekutan pembuktian formil, yang berarti membuktikan antara para pihak bahwa mereka telah menerangkan apa yang ditulis dalam akta tersebut; b) Kekuatan pembuktian materiil, yang berarti membuktikan antara para pihak, bahwa benar peristiwa yang tersebut dalam akta tersebut telah terjadi; dan c) Kekuatan pembuktian keluar, yang berarti disamping sebagai pembuktian antara mereka juga terdapat 
pihak ketiga di mana pada tanggal, bulan, dan tahun yang tersebut dalam tersebut telah menghadap kepada pegawai menerangkan apa yang terdapat dalam akta tersebut. Berdasarkan penelitian yang penulis lakukan terhadap Pelaksanaan Pembuatan akta Autentik Oleh Notaris di Kabupaten Lima Puluh Kota telah sesuai dengan Standar Operasional Prosedurnya (SOP), tetapi belum maksimal dengan adanya beberapa kendala.

\section{Kendala dalam Pelaksanaan Pembuatan akta Autentik Oleh Notaris di Kabupaten Lima Puluh Kota}

Berdasarkan wawancara dengan Ibu Elza Fitri S.H.,MKn, Bapak Khairul Nas S.H.,MKn dan Bapak Zainal Rajab S.H.,MKn sebagai Notaris di Kabupaten Lima Puluh Kota mengenai Kendala dalam Pelaksanaan Pembuatan akta Autentik Oleh Notaris di Kabupaten Lima Puluh Kota adalah sebagai berikut: 1) Para pihak/penghadap yang datang kekantor notaris tidak memahami tentang akta notaris dan tidak mengetahui sama sekali beda antara akta notaris dengan akta bawah tangan; 2) Para pihak/penghadap yang datang kekantor notaris tidak mengetahui tentang prosedur pengurusan akta autentik khususnya akta notaris, contohnya dalam pembuatan akta pendirin CV; 3) Para pihak/penghadap yang datang kekantor notaris beranggapan tentang biaya Pembuatan akta notaris tinggi, sehinga setelah datang yang pertama dan tidak datang lagi untuk selanjutnya setelah konsultasi dengan notaries; 4) Para pihak/penghadap yang datang kekantor notaries, sering tidak sabar dengan waktu pengurusan akta tersebut, karena sistim pengurusannya on line, ketika jaringan bermasalah maka waktunya tidak sesuai dengan prediksi awal para pihak/penghadap pegurusan akta CV tersebut dari awal sampai selesainya akta tersebut' dan 5) Dalam pembuatan akta sebuah PT sulit menghadirkan para pihak tersebut yang mana domosilinya berjauhan karena ada yang diluar kota apalagi dengan covid-19 sekarang ini agak kesulitan untuk menghadiri semuanya itu. Yang dimaksud dengan para pihak/penghadap untuk PT adalah pemegang saham perusahaan.

Dari hasil penelitian penulis dapat terlihat bahwa masyarakat masih di Kabupaten Lima Puluh Kota enggan untuk melakukan pengikatan, dengan akta notaris yang disebabkan oleh banyak hal namun yang paling menonjol adalah :

1. Biaya Pembuatan akta notaris tinggi. Banyak masyarakat yang beranggapan bahwa biaya pembuatan pengikatan dan hubungan hukum antara sesama anggota masyarakat dikantor notaris biayanya tinggi sekali, padahal jika dibandingkan dengan nilai objek dan jaminan hukum dari pembuatan akta tersebut dan pertanggung jawabannya biaya akta notaris masih tergolong rendah, namun dalam hal ini bukan masalah biaya yang mesti terlalu diperhitungkan tetapi manfaatnya dikemudian hari perlu juga diperhatikan. Berdasarkan Pasal 36 dari Udang-Undang Nomor 2 Tahun 2014 Tentang Perubahan Undang-Undang Nomor 30 Tahun 2004 Tentang Jabatan Notaris bahwa honorarium Notaris adalah: (1) Notaris berhak menerima honorarium atas jasa hukum yang diberikan sesuai dengan kewenangannya. (2) Besarnya honorarium yang diterima oleh Notaris didasarkan pada nilai ekonomis dan nilai sosiologis dari setiap akta yang dibuatnya. (3) Nilai ekonomis sebagaimana dimaksud pada ayat (2) ditentukan dari objek setiap akta sebagai berikut; a) Sampai dengan Rp100.000.000,00 (seratus juta rupiah) atau ekuivalen gram emas ketika itu, honorarium yang diterima paling besar adalah 2,5\% (dua koma lima persen); b) Di atas Rp100.000.000,00 (seratus juta rupiah) sampai dengan Rp1.000.000.000,00 (satu miliar rupiah) honorarium yang diterima paling besar 1,5 \% (satu koma lima persen); atau; c) Di atas Rp1.000.000.000,00 (satu miliar rupiah) honorarium yang diterima didasarkan pada kesepakatan antara Notaris dengan para pihak, tetapi tidak melebihi $1 \%$ (satu persen) dari objek yang dibuatkan aktanya. Nilai sosiologis ditentukan berdasarkan fungsi sosial dari objek setiap akta dengan honorarium yang diterima paling besar Rp5.000.000,00 (lima juta rupiah).

2. Tingkat pemahaman masyarakat masih rendah. Pada saat sekarang ini tingkat pendidikan masyarakat sudah mulai meningkat jika dibandingkan dengan beberapa tahun lalu namun sudah meningkatnya tingkat pendidikan masyarakat belum tercermin 
dari peningkatan kesadaran hukum masyarakat terhadap segala bentuk perbuatan hukum seperti pembuatan akta autentik dengan akta notaris, namun pada masyarakat yang kurang pendidikan hal ini dapat kita maklumkan karena mereka memang tidak mengerti dan tidak tahu dengan persoalan akta autentik/akta notaris.

3. Pembuatan akta notaris memiliki banyak prosedur dan syarat-syaratnya. Prosedur dan syarat-syarat pembuatan akta notaris menjadi masalah bagi sebagian masyarakat apabila masyarakat tidak mampu untuk memenuhi syarat-syarat yang diajukan notaris dan menganggap urusannya berbelit-belit padahal prosedur dan syarat-syarat merupakan kelengkapan dari pembuatan akta notaris sehingga akta tersebut menjadi autentik karena telah dipenuhinya syarat-syarat yang dibutuhkan sehingga tidak ada lagi keragu-raguan dalam pembuatan akta tersebut itu sendiri misalnya seseorang yang akan membuat sebuah perjanjian sewa menyewa dengan orang lain tidak memiliki sertifikat dari tanah yang akan ia sewakan tersebut sehingga notaris menyuruh untuk mengurus sertifikat terlebih dahulu agar jelas kedudukan dan kepemilikan dari tanah tersebut namun suruhan ini malah dianggap mempersulit untuk membuat sebuah perjanjian sewa menyewa dengan akta notaris.

4. Kesadaran Hukum masyarakat masih kurang.Disamping faktor-faktor diatas faktor kesadaran hukum merupakan hal yang penting karena dengan kesadaran masyarakat mau melaksanakan apa yang diinginkannya, terbukti dengan enggannya masyarakat untuk datang kekantor notaris dan lebih memilih untuk membuat secara bawah tangan yang dianggap lebih mudah dan gampang untuk dilakukan.

Disamping beberapa faktor diatas mungkin masih banyak alasan lain bagi sebagian dari anggota masyarakat yang enggan untuk membuat akta autentik dengan menggunakan akta notaris diantaranya lama sekali prosedur pembuatannya dan sering tidak sabar dengan waktu pengurusan akta tersebut, karena sistim pengurusannya on line, ketika jaringan bermasalah maka waktunya tidak sesuai dengan prediksi awal para pihak/penghadap pengurusan akta CV, PT dan Yayasan tersebut dari awal sampai selesainya akta tersebut, pada hal lama cepatnya sudah sebuah akta notaris tergantung dari kelengkapan data-data yang diberikan, tidak adanya kesepakatan para pihak dan alasan-alasan lain yang mungkin timbul dari anggota masyarakat itu sendiri.

Penggunaan akta notaris secara elektronik masih menjadi kontroversi antara para ahli mengenai kedudukannya, apakah akta notaris yang dibuat secara elektronik memiliki kekuatan hukum pembuktian akta autentik atau disamakan sebagai akta di bawah tangan. Pasal 1 angka 7 UUJN menyebutkan pengertian akta notaris adalah: akta autentik yang dibuat oleh atau di hadapan notaris menurut bentuk dan tata cara yang ditetapkan di dalam undang-undang ini.

Berdasarkan pengertian di atas dapat di simpulkan bahwa tentang penggolongan akta autentik terbagi menjadi beberapa macam yaitu: a) Akta autentik yang dibuat oleh pejabat umum disebut juga akta relaas (relaas acten), yaitu akta yang berisikan berupa uraian notaris yang dilihat, disaksikan, dan dibuat notaris sendiri atas permintaan para pihak, agar tindakan atau perbuatan para pihak dilakukan dan dituangkan ke dalam bentuk akta notaris. Kebenaran akta ini tidak dapat di ganggu gugat kecuali dengan menuduh bahwa akta itu palsu; dan b) Akta autentik yang dibuat dihadapan pejabat umum disebut juga akta partij (partij acten) atau akta para pihak, yaitu akta yang berisikan keterangan yang dikehendaki oleh para pihak yang membuatnya atau menyuruh membuat akta itu, yang kebenaran isi akta tersebut oleh para pihak dapat diganggu gugat tanpa menuduh kepalsuan akta tersebut.

Berdasarkan ketentuan Pasal 1868 KUHPerdata yang menyatakan bahwa agar suatu akta mempunyai kekuatan otentisitas, maka harus memenuhi beberapa syaratsyarat yaitu sebagai berikut: a) Aktanya itu harus di buat oleh atau di hadapan pejabat umum; dan b) Aktanya harus dibuat di dalam bentuk yang ditentukan oleh undang-undang dan pejabat umum itu harus mempunyai kewenangan untuk membuat akta tersebut.

Tujuan pembuatan akta notaris sesuai dengan fungsi dari akta notaris yakni untuk memperoleh kepastian hukum atas peristiwa hukum yang dilakukan oleh para pihak. Secara

376 Lembaga Penelitian dan Penerbitan Hasil Penelitian Ensiklopedia $\quad$ E-ISSN: 2657-0300

P-ISSN: 2657-0319 
umum akta notaris memiliki fungsi sebagai berikut: a) Akta sebagai fungsi formal yang mempunyai arti bahwa suatau perbuatan hukum akan menjadi lebih lengkap apabila di buat suatu akta. Perbuatan hukum harus dituangkan dalam bentuk akta sebagai syarat formil yaitu perbuatan hukum yang disebutkan dalam Pasal 1767 KUHPerdata mengenai perjanjian utang piutang. Minimal terhadap perbuatan hukum yang disebutkan dalam Pasal 1767 KUHPerdata, disyaratkan adanya akta bawah tangan; dan b) Akta sebagai alat pembuktian, di mana dibuatnya akta tersebut oleh para pihak yang terikat dalam suatu perjanjian di tujukan untuk pembuktian di kemudian hari.

Akta autentik merupakan alat pembuktian yang sempurna bagi kedua belah pihak dan ahli warisnya serta sekalian orang yang mendapatkan hak darinya tentang apa yang di muat dalam akta tersebut. Akta autentik juga merupakan bukti yang mengikat berarti kebenaran dari hal-hal yang tertulis dalam akta tersebut harus diakui oleh hakim, yaitu akta tersebut dianggap sebagai benar selamaa kebenarannya itu tidak ada pihak lain yang dapat membuktikan sebaliknya. Sebaliknya akta di bawah tangan dapat menjadi alat pembuktian yang sempurna terhadap orang yang menandatangani serta para ahli warisnya dan orang-orang yang mendapatkan hak darinya hanya apabila tanda tangan dalam akta di bawah tangan tersebut di akui oleh orang terhadap siapa tulisan itu hendak di pakai. Dalam aktivitas bisnis dan pergaulan masyarakat sehari-hari, banyak kegiatan yang menimbulkan perikatan. Perikatan dapat lahir dari persetujuan yang menimbulkan hak dan kewajiban baik karena undang-undang atau karena perjanjian yang dibuat oleh antar pihak. Suatu perikatan dilakukan oleh subjek hukum, yaitu orang alamiah (natuurlijk person) maupun badan hukum (recht person) dengan syarat-syarat yang diatur oleh peraturan perundang-undangan. Perikatan dengan dasar perjanjian dapat dikategorikan sebagai perbuatan hukum, karena perikatan dengan dasar perjanjian selain menimbulkan hak dan kewajiban dapat juga menimbulkan suatu resiko hukum diantara para pihak, oleh karenanya banyak pihak yang melakukan perjanjian tertulis dengan menggunakan jasa notaris untuk membuat akta perjanjian sebagai alat pembuktiannya.

Berdasarkan Pasal 1867 KUH Perdata atau dalam bahasa Belanda disebut sebagai burgerlijk wetbook (yang biasa disingkat BW), dikenal alat pembuktian tertulis sebagai berikut: 1) Pembuktian dengan tulisan/akta autentik. Berdasarkan Pasal 1868 akta autentik ialah suatu akta yang dibuat dalam bentuk yang ditentukan undang-undang oleh atau dihadapan pejabat umum yang berwenang untuk itu di tempat akta itu dibuat. Pasal 1 angka 1 UUJN menyebutkan pejabat umum yang berwenang untuk membuat akta autentik adalah Notaris; 2) Tulisan/akta di bawah tangan, berdasarkan Pasal 1874, yang dianggap sebagai tulisan di bawah tangan adalah akta yang ditandatangani di bawah tangan, surat, daftar, surat urusan rumah tangga dan tulisan-tulisan yang lain yang dibuat tanpa perantaraan seorang pejabat umum. Notaris memiliki kewenangan untuk membuat Akta autentik mengenai semua perbuatan, perjanjian, dan penetapan yang diharuskan oleh peraturan perundangundangan dan/atau yang dikehendaki oleh yang berkepentingan untuk dinyatakan dalam Akta autentik, menjamin kepastian tanggal pembuatan Akta, menyimpan Akta, memberikan grosse, salinan dan kutipan Akta, semuanya itu sepanjang pembuatan Akta itu tidak juga ditugaskan atau dikecualikan kepada pejabat lain atau orang lain. (Pasal 15 UUJN).

Masyarakat yang membuat akta notaris mereka memiliki alasan: a) Akta notaris kepastiannya lebih terjamin. Akta notaris yang merupakan akta autentik yang lebih terjamin dan memiliki kepastian hukum bila dibanding dengan akta lainnya, para pihak tidak lagi merasa ragu dan was-was jika salah satu pihak tidak memenuhi janjinya dan ada bukti yang mengikat mereka kedua belah pihak dan apabila dibawa kepengadilan akta notaris lebih terjamin kekuasaan hukumnya dibandingkan dengan yang lain; b) Akta autentik lebih mengikat kedua belah pihak dan lebih diakui. Oleh orang lain ada sebagian masyarakat menilai bahwa dengan dibuatnya pengikatan dengan akta autentik mereka kedua belah pihak yang melakukan pengikatan lebih mengikat dan tidak ada pertentangan lagi berhubungan dengan pengikatan telah diatur dalam akta notaris namun ada sebagian masyarakat tidak memahami bahwa arti penting sesungguhnya dari akta autentik adalah dari segi kekuatan hukumnya; dan c) Akta autentik memiliki kekuatan hukum yang tinggi dari pada akta lainnya. Sebagian 
masyarakat yang telah mengerti hukum dan memiliki tingkat pendidikan yang tinggi memiliki kekuatan hukum yang tinggi jika dibandingkan dengan akta lainnya, karena alasan inilah masyarakat membuat akta autentik. Para praktisi hukum seperti notaris, pengacara dan para penegak hukum lainnya memiliki alasan bahwa dengan akta notaris setiap pengikatan yang dilakukan kepastian hukumnya terjamin dan tidak ada para pihak yang akan menggugatnya karena para pihak dalam membuat akta notaris saling berhadapan sehingga tidak ada lagi kecurangan yang dilakukan dan jika persoalan pengikat ini dibawa ke pengadilan maka kekuatan hukumnya mengikat dan para pihak yang membawa akta notaris sebagai bukti adalah pihak yang diuntungkan.

\section{Jalan keluar terhadap kendala dalam Pelaksanaan Pembuatan Akta Autentik Oleh Notaris di Kabupaten Lima Puluh Kota}

Berdasarkan hasil wawancara penulis dengan Bapak Zainal Rajab S.H.,MKn sebagai salah seorang Notaris di Kabupaten Lima Puluh Kota, mengenai Jalan keluar terhadap kendala dalam Pelaksanaan Pembuatan Akta Autentik Oleh Notaris adalah sebagai berikut: 1) Meningkatkan pemahaman para pihak/penghadap tentang akta autentik, karena banyak para pihak/penghadap yang datang kekantor notaris tidak memahami apa itu akta autentik/akta notaris sehingga mereka tidak mengetahui apa guna mereka membuat akta notaris; 2) Memberikan penjelasan kepada para pihak/penghadap yang datang kekantor notaris yang tidak memahami hukum terutama tentang prosedur pembuatan akta notaris; 3) Menjelaskan kepada para pihak/penghadap yang datang kekantor notaris dan merubah pola pikir serta anggapan masyarakat tentang Biaya Pembuatan akta notaris tinggi; dan 4) Memberikan penjelasan dan pemahaman kepada para pihak/penghadap yang datang kekantor notaris dan karena sistim pengurusannya on line, ketika jaringan bermasalah maka waktunya tidak sesuai dengan prediksi awal para pihak/penghadap tersebut.

Seorang notaris adalah pejabat umum yang diberikan wewenang untuk membuat akta otentik dalam arti menyusun, membacakan dan menandatangani serta diberi wewenang membuat akta dalam bentuk yang ditentukan oleh Undang-undang menurut Kitab Undangundang Hukum Perdata dan Undang-undang Jabatan Notaris. Notaris dapat dimintai tanggungjawab apabila notaris melakukan perbuatan melawan hukum, Tanggungjawab yang dapat diminta kepada notaris adalah sebagai berikut :

a. Tanggungjawab Notaris Secara Administrasi. Tanggung jawab hukum Notaris dalam membuat akta secara administratif dapat dilihat dari bentuk sanksi yang diberikan atas pelanggaran terhadap kewajiban yang dibebankan kepada Notaris. Pasal 16 ayat (11) menyatakan sanksi berupa: peringatan tertulis; pemberhentian sementara; pemberhentian dengan hormat; atau pemberhentian dengan tidak hormat. Sanksi-sanksi tersebut diberikan apabila Notaris melanggar ketentuan Pasal 16 ayat (1) huruf a sampai dengan 1 sehubungan dengan tugas Notaris dalam membuat akta. Sifat sanksi pada ayat tersebut menurut pendapat penulis adalah sanksi yang bersifat administratif

b. Tanggungjawab Notaris Secara Perdata. Notaris dalam membuat akta bertanggung jawab secara perdata dengan melihat sanksi yang diberikan kepada Notaris merupakan sanksi perdata. Sanksi tersebut berupa penggantian biaya, ganti rugi, dan bunga kepada pihak yang dirugikan. Sanksi tersebut dapat dijatuhkan bersamaan dengan sanksi administrative. Ketentuan mengenai sanksi perdata terhadap Notaris juga terlihat pada ketentuan Pasal 44 ayat (5) UUJN. Notaris yang melanggar ketentuan sebagaimana dimaksud pada ayat (1), ayat (2), ayat (3) dan ayat (4) Pasal 44 UUJN dapat dituntut ganti rugi dan bunga oleh pihak yang karena kelalaian Notaris pihak tersebut menderita kerugian. Pasal 41 UUJN juga memuat ketentuan mengenai kebatalan akta Notaris apabila tidak memenuhi ketentuan Pasal 38, Pasal 39, dan Pasal 40 tentang bentuk, kedudukan cakap bertindak para pihak serta saksi dalam membuat akta Notaris. Pasal 1243 KUH Perdata memberikan ketentuan bahwa pihak yang lalai untuk memenuhi suatu perikatan maka dapat dituntut oleh pihak yang merasa dirugikan atas tidak 
dipenuhinya prestasi dalam perikatan tersebut, tuntutan tersebut antara lain; ganti rugi berupa penggantian biaya-biaya dan kerugian yang diderita serta keuntungan yang seharusnya diperoleh. Apabila pihak yang menghadap kepada Notaris merasa dirugikan karena Notaris tidak melaksanakan kewajibannya sesuai dengan ketentuan di dalam UUJN, maka penghadap dapat menuntut kepada Notaris berupa penggantian biaya-biaya yang telah dikeluarkan, ganti kerugian dan bunga atau keuntungan yang seharusnya diperoleh. Tanggung jawab Notaris yang demikian itu disebut dengan tanggung jawab perdata. Sanksi ini diberikan kepada Notaris apabila Notaris melakukan pelanggaran yang mengakibatkan kerugian oleh pihak yang menghadap atau meminta bantuan jasa kepada Notaris, sehingga akibat dari kerugian tersebut dapat menjadi alasan untuk menuntut penggantian biaya, ganti rugi, dan bunga kepada Notaris. Apabila Notaris tidak melaksanakan tanggung jawabnya, maka alasan tersebut dapat dijadikan dasar oleh pihak penghadap yang dirugikan untuk melakukan gugatan ke pengadilan, berdasarkan bukti pelanggaran yang dilakukan oleh Notaris.

c. Tanggungjawab Notaris Secara Pidana. Tanggung jawab hukum Notaris secara pidana adalah tanggung jawab yang harus dilaksanakan oleh Notaris, apabila Notaris terbukti secara sah dan benar bahwa perbuatan Notaris dalam membuat akta memenuhi unsurunsur perbuatan pidana, Notaris dalam menjalankan tugas jabatannya tidak menutup kemungkinan untuk dapat dikenai tanggung jawab secara pidana. Hal tersebut dapat dilihat dari unsur-unsur tindak pidana yang diatur di dalam Kitab Undang-Undang Hukum Pidana (KUHP). Sanksi yang diberikan bagi Notaris yang melakukan perbuatan pidana dalam membuat akta autentik juga merupakan sanksi pidana sebagaimana diatur di dalam KUHP, dan bukan sanksi yang diberikan oleh UUJN. Setiap pelanggaran yang dilakukan oleh Notaris, UUJN hanya memberikan sanksi berupa sanksi perdata dan sanksi administratif. Sanksi pidana dapat diberikan kepada Notaris salah satunya adalah apabila Notaris membuka rahasia yang wajib disimpannya dalam menajalankan jabatan Notaris. Pasal 322 ayat (1) KUHP megatakan bahwa: "Barang siapa dengan sengaja membuka rahasia yang wajib disimpannya karena jabatan atau pencahariannya, baik yang sekarang maupun yang dahulu, diancam dengan pidana penjara paling lama sembilan bulan atau denda paling banyak sembilan ribu rupiah."

Ketentuan tersebut sesuai dengan kewajiban Notaris untuk menyimpan rahasia terhadap seluruh informasi terhadap akta yang dibuatnya, sebagaimana diatur dalam Pasal 4 ayat (2), Pasal 16 ayat (1) furuh f, dan Pasal 54 ayat (1) UUJN. Notaris hanya dapat bertanggung jawab secara pidana dalam perbuatan di atas apabila pihak yang merasa dirugikan, atau pihak yang bersangkutan dengan akta tersebut mengadukan perbuatan Notaris ke polisi atau penegak hukum lainnya (Pasal 322 ayat (2) KUHP).

\section{Penutup}

Berdasarkan penelitian yang penulis lakukan mengenai Pelaksanaan Pembuatan akta Autentik Oleh Notaris di Kabupaten Lima Puluh Kota maka penulis dapat menyimpulkan sebagai berikut: Para pihak/penghadap datang melakukan konsultasi kekantor notaris konsultasi dan menyampaikan apa yang menjadi keinginannya, notaris menjelaskan semuanya kepada para pihak/penghadap kalau sudah dilengkapi semuanya oleh para pihak/ penghadap, maka akan ditandatangani akta oleh para pihak (minuta/akta) dan akan dikeluarkan salinannya oleh notaris dan ditandatangani diatas matrai, jadi berdasarkan penelitian yang penulis lakukan terhadap Pelaksanaan Pembuatan akta Autentik Oleh Notaris di Kabupaten Lima Puluh Kota telah sesuai dengan Standar Operasional Prosedurnya (SOP), tetapi belum maksimal dengan adanya beberapa kendala. Kendala dalam Pelaksanaan Pembuatan akta Autentik Oleh Notaris di Kabupaten Lima Puluh Kota adalah: para pihak/penghadap yang datang kekantor notaris tidak memahami tentang akta notaris dan tidak mengetahui sama sekali beda antara akta notaris dengan akta bawah tangan dan para pihak/penghadap beranggapan tentang biaya Pembuatan akta notaris tinggi serta para pihak/penghadap sering tidak sabar dengan waktu pengurusan akta tersebut, karena sistim pengurusannya on line, 
ketika jaringan bermasalah maka waktunya tidak sesuai dengan prediksi awal para pihak/penghadap pegurusan akta baik CV,PT maupun yayasan tersebut dari awal sampai selesainya akta tersebut. Jalan keluar terhadap kendala dalam Pelaksanaan Pembuatan Akta Autentik Oleh Notaris adalah sebagai berikut: meningkatkan pemahaman para pihak/penghadap tentang akta autentik, memberikan penjelasan kepada para pihak/penghadap tentang prosedur pembuatan akta notaris, baik CV, PT maupun Yayasan dan menjelaskan kepada para pihak/penghadap yang datang kekantor notaris dan merubah pola pikir serta anggapan masyarakat tentang biaya pembuatan akta notaris tinggi serta memberikan penjelasan dan pemahaman kepada para pihak/penghadap yang datang kekantor notaris dan karena sistim pengurusannya on line, ketika jaringan bermasalah maka waktunya tidak sesuai dengan prediksi awal para pihak/penghadap tersebut.

\section{Daftar Pustaka}

Abdul Ghofur Anshori, 2009, Lembaga Kenotariatan Indonesia, Perspektif Hukum dan Etika, UII Press;

Bambang Sugeng A.S., dan Sujayadi, 2011, Hukum Acara Perdata dan Dokumen Litigasi Perkara Perdata Kencana, Jakarta;

Daeng Naja, 2012, Teknik Pembuatan Akta,Pustaka Yustisia, Sinar Baru, Bandung;

Habib Adjie, 2015, Penggerogotan Wewenang Notaris Sebagai Pejabat Umum”, Sinar Baru, Bandung Yogyakarta;

Hartanti Sulihandri dan Nisya Rifiani, 2013, Prinsip-prinsip dasar profesi Notaris,CipayungJakarta,

Herlien Budiono, 2012, Kumpulan Tulisan Hukum Perdata di Bidang Kenotariatan, PT Citra Aditya Bakti Bandung;

Selo Sumarjan, 1995, Perkembangan Politik Sebagai Penggerak Dinamika Pembangunan Ekonomi, Universitas Indonesia Press, Jakarta;

Soerjono Soekanto, 1982, Kesadaran Hukum dan Kepatuhan Hukum, Rajawali Press, Jakarta;

Subekti, S.H., 2003, Pokok-pokok Hukum Perdata, 2003, PT Intermasa, Jakarta.

Undang-Undang Dasar 1945

Kitab Undang-Undang Hukum Perdata (KUHPerdata);

Undang-Undang Nomor 2 Tahun 2014 Republik Indonesia Tentang Jabatan Notaris

Bulatak manah, http://balangsakmanah.blogspot.com/2013/12/akta-otentik-sebagaialat-buktiyang.html. 